\title{
Concentration and depuration of some radionuclides present in a chronically exposed population of mussels (Mytilus edulis)
}

\author{
R. J. Clifton, H. E. Stevens and E. I. Hamilton \\ Natural Environment Research Council, Institute for Marine Environmental Research, Prospect Place, The Hoe, Plymouth, \\ PLI 3DH, Devon, England
}

\begin{abstract}
Factors are described which affect the concentration ( $\mathrm{p} \mathrm{Ci} \mathrm{g}{ }^{-1}$ dry wt) and loss of ${ }^{241} \mathrm{Am}$, ${ }^{239}+{ }^{240} \mathrm{Pu},{ }^{238} \mathrm{Pu},{ }^{144} \mathrm{Ce},{ }^{137} \mathrm{Cs},{ }^{134} \mathrm{Cs},{ }^{106} \mathrm{Ru},{ }^{95} \mathrm{Zr}$ and ${ }^{95} \mathrm{Nb}$ in an exposed population of mussels Mytilus edulis L. from Ravenglass on the Esk estuary, Cumbria, UK which receives radioeffluents from the British Nuclear Fuels Ltd. (BNFL) plant at Sellafield, some $10 \mathrm{~km}$ to the north. Tidal position and mussel body size have a negligible influence on the concentration of ${ }^{241} \mathrm{Am},{ }^{137} \mathrm{Cs}$ and ${ }^{106} \mathrm{Ru}$ in the total soft tissue, but variation in soft tissue weight throughout the year has a considerable influence on the apparent concentration and depuration times of these radionuclides. Apart from the clearance $\left(t_{1 / 2}\right.$ biol, 1 to $3 \mathrm{~h}$ ) of sediment-associated activity from the digestive tract, the depuration rate profiles follow a single component clearance curve with a biological half-life in excess of $200 \mathrm{~d}$ for ${ }^{241} \mathrm{Am},{ }^{239}+{ }^{240} \mathrm{Pu}$, ${ }^{238} \mathrm{Pu}$ and ${ }^{144} \mathrm{Ce}$, and of $40 \mathrm{~d}$ for ${ }^{137} \mathrm{Cs}$. The clearance of ${ }^{106} \mathrm{Ru}$ is more complex and consists of a 3 component depuration profile with biological half-lives of $6 \mathrm{~h}, 12 \mathrm{~d}$ and $260 \mathrm{~d}$. The depuration profiles presented in this work are for chronically ingested isotopes under natural conditions; acute exposure will most likely result in different profiles, especially those derived from laboratory spiking experiments. Isotope ratio data support the hypothesis that the main route of entry into the mussel for the majority of the radionuclides studied is from the water. Differences in the biological half-lives observed between ${ }^{239}+{ }^{240} \mathrm{Pu}$ and both ${ }^{238} \mathrm{Pu}$ and ${ }^{241} \mathrm{Am}$ could be related to their different physico-chemical forms rather than a biological mechanism differentiating between these isotopes; as there are no suitable data available for the composition (chemical or physical) of the BNFL effluent it is not possible to determine whether these differences reflect procedures employed during fuel reprocessing or sediment-water interactions after discharge. This paucity of information also makes it difficult to determine the degree to which the Ravenglass mussels reflect recent discharges from BNFL.
\end{abstract}

\section{INTRODUCTION}

The mussel Mytilus edulis L. has been identified as a good 'sentinel' or 'indicator' species for trace elements and is particularly efficient in accumulating transuranium isotopes (Goldberg et al., 1978), as well as other radioisotopes present in the estuarine environment.

The data on mussels, chronically exposed to radioactive isotopes, are generally limited to monitoring surveys which report the concentrations of selected radioisotopes originating from either nuclear weapon test fallout (Pillai et al., 1964; Noshkin, 1972; Bowen et al., 1976; Murray and Fukai, 1978; Goldberg et al., 1978) or from nuclear fuel reprocessing plants (Hetherington et al., 1976; Pillai and Mathew, 1976; Guary and Frazier, 1977; Hamilton and Clifton, 1980).
These studies do not, in general, consider turnover rates or physiological and environmental factors which may influence the uptake and elimination of radionuclides from these animals.

Several authors (Seymour and Nelson, 1972; Van Weers, 1972; Fowler et al., 1975a; Guary and Fowler, 1977, 1978, 1981; Dahlgaard, 1981 and Fowler et al., 1981) have studied the turnover of a variety of radionuclides in the mussel and in some cases consider factors, such as weight change and temperature, which may influence their concentration and turnover rates. With the exception of Seymour and Nelson's (1972) work on the depuration of ${ }^{65} \mathrm{Zn}$ from a chronically exposed mussel population after the shutdown of the Hanford reactors (Richland, Washington, USA), all of these studies have been confined to animals which have been 'spiked' with the radionuclide of interest 
under laboratory conditions, over periods of time ranging from 20 to $90 \mathrm{~d}$. As the biological half-life of a particular radionuclide will vary according to the exposure route, length of exposure (Fowler et al., 1975b, The International Mussel Watch, 1980) and environmental conditions (Guary and Fowler, 1977), some caution has to be exercised when extrapolating these results to chronically contaminated naturally exposed populations, as a much longer time period may normally be required for such animals to equilibriate with environmental levels. In the case of ${ }^{65} \mathrm{Zn}$ and ${ }^{60} \mathrm{Co}$, Van Weers (1975) has estimated that it would require about $200 \mathrm{~d}$ for the long-lived component in mussel to approach equilibrium with the seawater.

We have studied the depuration profiles for a variety of radionuclides in a mussel population from the Esk estuary, exposed in situ to a variable but continuous source of radioisotopes resulting from the discharge of waste from the British Nuclear Fuels Ltd. (BNFL) reprocessing plant at Sellafield, Cumbria, into the N. E. Irish Sea. Turnover times have been studied in conjunction with local environmental and metabolic variables which may influence the concentration and biological half-lives of these radioisotopes in the total soft tissue of the mussel. To this end both the resident population of the Esk and a transplant of 4000 individuals from the Esk to Millbay in Plymouth were studied.

\section{METHODOLOGY}

Mussels Mytilus edulis L. were collected from a population in the Esk estuary (Fig. 1) adjacent to the village of Ravenglass in Cumbria, UK. Three distinct sampling regimes were adopted:

(i) In September 1980, samples ranging in shell length from 2 to $8 \mathrm{~cm}$,were taken along 3 transects across the mussel bed, parallel to the low water mark (LWM). Transects A and C sampled the mussel population at the low water mark and at the highest bed level respectively, while Transect $B$ sampled the population at a tidal level mid-way between A and C. Each transect sample of 150 individuals was further subdivided into 3 groups according to shell length. Two subsamples (50 to 60 individuals) were also taken from Transect $\mathrm{A}$ and $\mathrm{C}$ and transferred to laboratory aquaria where they were kept starved, in filtered, aerated sea water at $10^{\circ} \mathrm{C}$ on plastic grills (to minimise recycling of faecal material) for $48 \mathrm{~h}$, during which time the water was changed 4 times. The mass of faecal material was determined after filtration and drying and the results expressed as mg faeces $\mathrm{g}^{-1}$ dry mussel tissue.

(ii) Sixty individuals ( 4.5 to $6 \mathrm{~cm}$ in length) were taken from the mussel bed, towards the LWM, at approximately $6 \mathrm{wk}$ intervals between September 1980 and September 1981.

(iii) Four thousand individuals ( 4.5 to $6 \mathrm{~cm}$ in length) were taken from the Ravenglass population in September 1980, cleaned of epibota and rinsed in $0.45 \mu \mathrm{m}$ Millipore membrane filtered local sea water; 500 of these were transferred to laboratory aquaria where they were kept, starved, on plastic grills suspended in filtered, aerated sea water at $10^{\circ} \mathrm{C}$; the water was changed every hour. Fifty to 60 of these individuals were sub-sampled at time intervals ranging from 1 to $48 \mathrm{~h}$. The remainder were transplanted into 2 cages, secured to bedrock in the Millbay area of Plymouth Sound, close to the mouth of the River Tamar (Fig. 1) where the levels of the nuclides of interest were at least 2 orders of magnitude lower than those found in the Esk estuary. One cage was anchored at the LWM and the other at a tidal level having a similar exposure period to that of the resident Esk population along Transect C. Unfortunately, however, the higher tidal level cage was vandalised shortly after transplantation and hence only data obtained from low-water-mark individuals is referred to in this work. The low-water mark samples were subsequently sub-sampled over the next 12 mo at approximately $5 \mathrm{wk}$ intervals.

Samples from the 3 groups were processed in the same way: all epibiotic growth was removed and the mussels were washed with filtered sea water; the shell length of each individual was measured (maximum anterior to posterior axial distance from the umbo); the shell was then opened allowing the water in the shell cavity to drain away; the total soft tissue, including

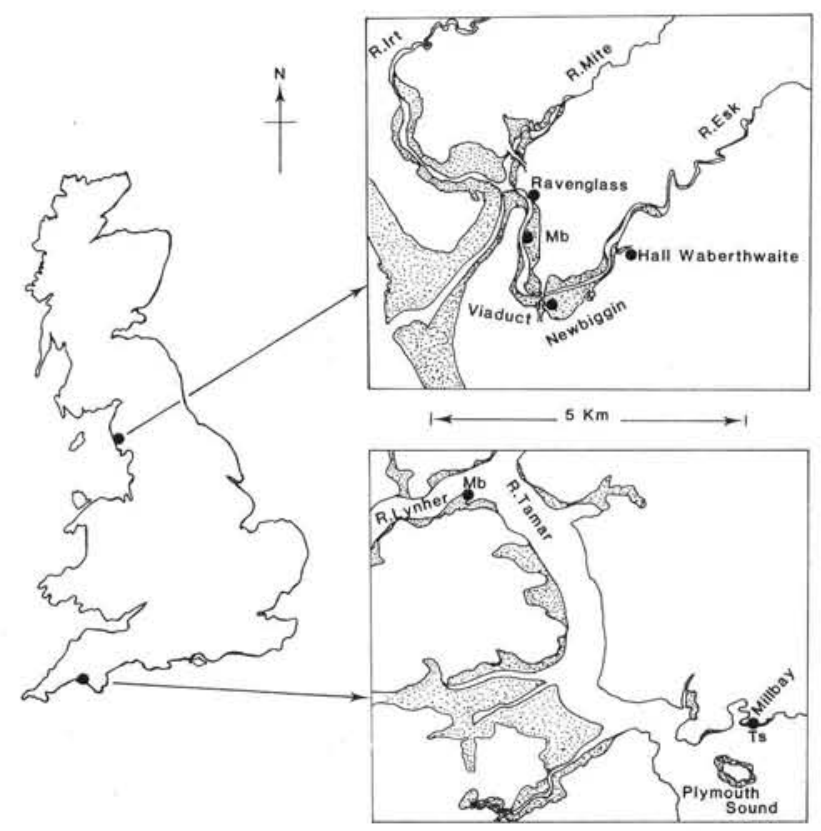

Fig. 1. Position of mussel beds (Mytilus edulis) (Mb) and transplant site (Ts) 
pallial fluid, was removed and weighed before and after freeze drying. The freeze-dried mussel tissue was reduced to a fine powder $(<50 \mu \mathrm{m})$ in a liquid-nitrogen mill (SPEX Industries Inc. Metuchen, N. J., USA), homogenised and sub-sampled for analyses. A subsample of these mussels ( $30 \%$ ) was also used for the determination of the Condition Index (C. I.) (Bayne and Widdows, 1978) for which the total mussel volume, shell volume and total tissue dry weight were determined separately, and the C. I. calculated from the relationship:

C. I. = Dry wt. of soft tissue/(mussel vol.) - (shell vol.)

Several 6-1 water samples, taken from the area of the mussel bed at high water in February 1981, were filtered twice through a $0.45 \mu \mathrm{m}$ Millipore membrane, and the ${ }^{106} \mathrm{Ru},{ }^{137} \mathrm{Cs}$ and ${ }^{134} \mathrm{Cs}$ content of the filtrate was determined by gamma counting $500 \mathrm{ml}$ directly. The ${ }^{239}+{ }^{240} \mathrm{Pu}$ and ${ }^{238} \mathrm{Pu}$ activities were determined separately in a further 51 of the same filtered sample by coprecipitation with ferric hydroxide, after adjusting the sample to $\mathrm{pH} 6$ and then boiling with $500 \mathrm{ml}$ of concentrated nitric acid; $5 \mathrm{~g}$ of $\mathrm{NaNO}_{2}$ (to ensure that the plutonium was in the quadrivalent state; Livingstone et al., 1975) and $100 \mathrm{mg}$ or iron carrier; ${ }^{239} \mathrm{Pu}$ was added as a tracer to determine chemical yields.

Three samples of Esk silt were taken in September 1980 from: the Ravenglass mussel bed (Level A); the area adjacent to the Eskmeals viaduct and from a site close to Hall Waberthwaite (Fig. 1). These sediment samples, together with the filtered suspended material, faeces and mussel tissue were freeze dried, homogenised and analysed for gamma emitters by the method described by Clifton and Hamilton (1982). The ${ }^{239}+{ }^{240} \mathrm{Pu}$ and ${ }^{238} \mathrm{Pu}$ content of these samples was determined by the methods described by Livingstone et al. (1975).

The total lipid content of the dried mussel tissue was determined by a modification of the Blight and Dyer (1959) method described by Thompson (1972).

\section{RESULTS AND DISCUSSION}

\section{Radionuclide concentration relative to shell length and tidal position}

The range of the size distribution is less for the mussels at the highest tidal level (Fig. 2). Any differences in the ${ }^{241} \mathrm{Am},{ }^{137} \mathrm{Cs}$ and ${ }^{106} \mathrm{Ru}$ concentrations in soft tissue with respect to shell length and tidal position (Table 1) may result from the mussels towards the high water mark being exposed to particulate material of a higher specific activity than those found towards the LWM. This interpretation, with the exception of the ${ }^{106} \mathrm{Ru}$ data, is supported by the higher nuclide concentrations found in the faecal material of mussels from Transect $\mathrm{C}$ relative to that collected from LWM individuals (Table 2 ).

\section{Radionuclide concentration of the mussel population at Ravenglass}

Fig. 3 shows the variation in radionuclide content of the Ravenglass mussel population corrected for weight changes throughout the year 1980-1981. The concentrations of ${ }^{241} \mathrm{Am},{ }^{144} \mathrm{Ce},{ }^{137} \mathrm{Cs},{ }^{134} \mathrm{Cs},{ }^{95} \mathrm{Zr}$ and ${ }^{95} \mathrm{Nb}$ reached a maximum in May, 1981, while the ${ }^{106} \mathrm{Ru}$ concentration reached a maximum a little earlier, in
Fig. 2. Mytilus edulis. Size distribution of Ravenglass mussels sampled towards high, low and mid-tide levels

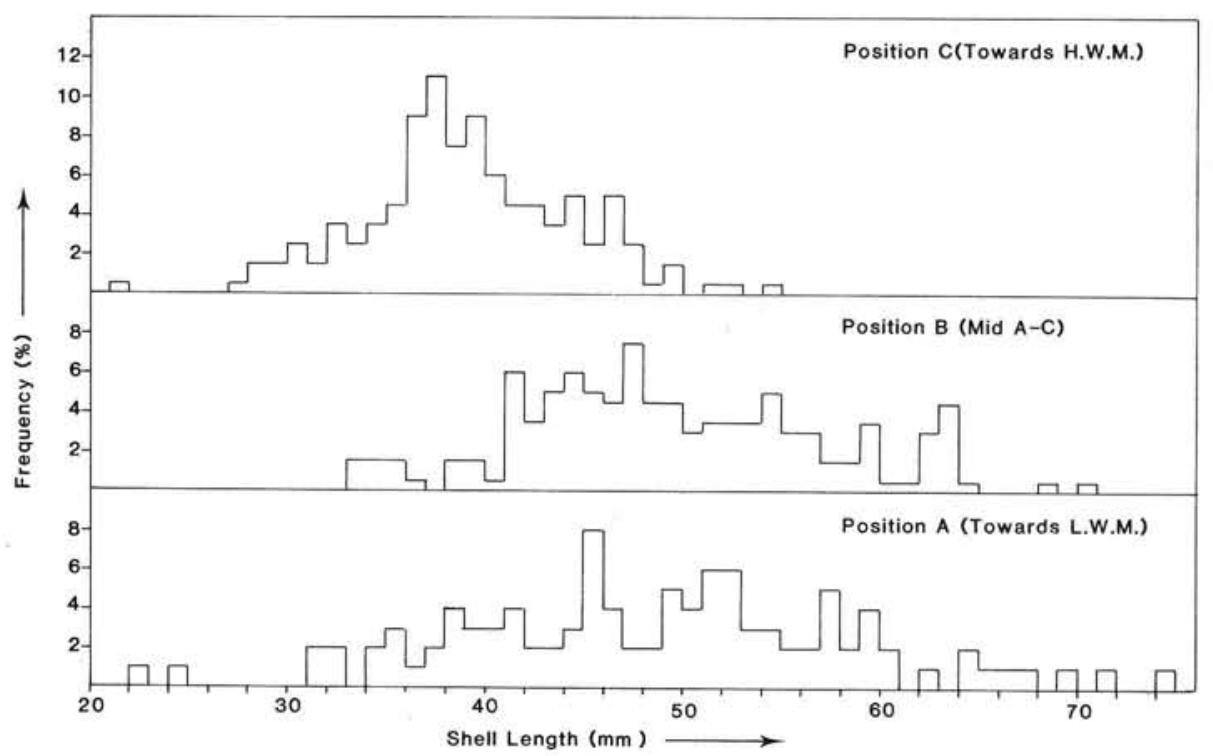


Table 1. Mytilus edulis. Concentration of ${ }^{241} \mathrm{Am},{ }^{137} \mathrm{Cs}$ and ${ }^{106} \mathrm{Ru}$ determined in the total soft tissue of the Ravenglass population with reference to tidal position and shell length; September $1980 .{ }^{*} \mathrm{p} \mathrm{Ci}^{-1}$ dry weight; counting error $=1.65 \sigma$, precision on triplicate determinations usually better than $12 \%$ (for $1.65 \sigma$ ). ${ }^{\cdots} \mathrm{Bq} \mathrm{g}^{-1}$ dry weight. $\cdots$ Error is $1 \sigma$ about the mean of the 3 determinations

\begin{tabular}{|c|c|c|c|c|c|}
\hline Tidal position & $\mathrm{N}$ & Shell length $(\mathrm{cm})$ & ${ }^{241} \mathrm{Am}^{*}$ & ${ }^{137} \mathrm{Cs}^{*}$ & ${ }^{106} \mathrm{Ru} \cdot$ \\
\hline Low tide & 36 & $3.89 \pm 0.53$ & $\begin{array}{c}1.85 \pm 0.32 \\
(0.07) \cdots\end{array}$ & $\begin{array}{c}21.1 \pm 0.4 \\
(0.78)\end{array}$ & $\begin{array}{c}101.3 \pm 3.1 \\
(3.75)\end{array}$ \\
\hline Low tide & 33 & $4.90 \pm 0.25$ & $\begin{array}{c}2.17 \pm 0.35 \\
(0.08)\end{array}$ & $\begin{array}{c}23.4 \pm 0.4 \\
(0.87)\end{array}$ & $\begin{array}{c}98.1 \pm 3.3 \\
(3.63)\end{array}$ \\
\hline Low tide & 35 & $5.99 \pm 0.51$ & $\begin{array}{c}4.32 \pm 0.36 \\
(0.16)\end{array}$ & $\begin{array}{c}23.7 \pm 0.4 \\
(0.88)\end{array}$ & $\begin{array}{c}101.1 \pm 3.2 \\
(3.74)\end{array}$ \\
\hline Mean $\cdots$ & & & $\begin{array}{c}2.78 \pm 1.10 \\
(0.10)\end{array}$ & $\begin{array}{c}22.7 \pm 1.2 \\
(0.84)\end{array}$ & $\begin{array}{c}100.2 \pm 1.5 \\
(3.71)\end{array}$ \\
\hline Mid tide & 40 & $4.03 \pm 0.31$ & $\begin{array}{c}4.50 \pm 0.79 \\
(0.17)\end{array}$ & $\begin{array}{c}23.8 \pm 0.6 \\
(0.88)\end{array}$ & $\begin{array}{c}115.1 \pm 4.8 \\
(4.26)\end{array}$ \\
\hline Mid tide & 50 & $4.77 \pm 0.23$ & $\begin{array}{c}3.84 \pm 0.54 \\
(0.14)\end{array}$ & $\begin{array}{c}23.4 \pm 0.6 \\
(0.87)\end{array}$ & $\begin{array}{c}105.9 \pm 5.9 \\
(3.82)\end{array}$ \\
\hline Mid tide & 43 & $5.77 \pm 0.42$ & $\begin{array}{c}5.33 \pm 0.55 \\
(0.20)\end{array}$ & $\begin{array}{c}24.8 \pm 0.7 \\
(0.92)\end{array}$ & $\begin{array}{c}113.7 \pm 6.1 \\
(4.21)\end{array}$ \\
\hline Mean & & & $\begin{array}{c}4.56 \pm 0.61 \\
(0.17)\end{array}$ & $\begin{array}{c}24.0 \pm 0.6 \\
(0.89)\end{array}$ & $\begin{array}{c}111.6 \pm 4.0 \\
(4.13)\end{array}$ \\
\hline High tide & 41 & $3.72 \pm 0.37$ & $\begin{array}{c}5.42 \pm 0.33 \\
(0.20)\end{array}$ & $\begin{array}{c}20.7 \pm 0.4 \\
(0.77)\end{array}$ & $\begin{array}{c}108.1 \pm 3.0 \\
(4.00)\end{array}$ \\
\hline High tide & 51 & $4.26 \pm 0.13$ & $\begin{array}{c}6.38 \pm 0.38 \\
(0.24)\end{array}$ & $\begin{array}{c}27.7 \pm 0.4 \\
(1.02)\end{array}$ & $\begin{array}{c}115.6 \pm 3.4 \\
(4.28)\end{array}$ \\
\hline High tide & 40 & $4.93 \pm 0.32$ & $\begin{array}{c}6.74 \pm 0.58 \\
(0.25)\end{array}$ & $\begin{array}{c}27.3 \pm 0.7 \\
(1.01)\end{array}$ & $\begin{array}{c}114.9 \pm 6.4 \\
(4.25)\end{array}$ \\
\hline Mean & & & $\begin{array}{c}6.18 \pm 0.56 \\
(0.23)\end{array}$ & $\begin{array}{c}25.2 \pm 3.2 \\
(0.93)\end{array}$ & $\begin{array}{c}112.9 \pm 3.4 \\
(4.18)\end{array}$ \\
\hline
\end{tabular}

March 1981. Significantly, Aston and Stanners (1982) reported that most locations, in the same estuary, had higher sediment fission product activities in May 1978 than the annual mean data. The relationship between the concentration of these radionuclides in the mussels of the Esk estuary and discharges from BNFL is extremely complex and difficult to interpret as it is dependent on a variety of often ill-defined factors including effluent composition, discharge frequencies, transit times and the influence of weather. From Table 3 it can be seen that the ${ }^{137} \mathrm{Cs} /{ }^{134} \mathrm{Cs}$ and the ${ }^{95} \mathrm{Zr} /$ ${ }^{95} \mathrm{Nb}$ ratios in mussel tissue vary throughout the year. The ${ }^{137} \mathrm{Cs} /{ }^{134} \mathrm{Cs}$ discharge ratios were 10.9 and 12.4 , and the ${ }^{95} \mathrm{Zr} /{ }^{95} \mathrm{Nb}$ discharge ratios were 0.61 and 0.59 respectively in 1979 and 1980 (BNFL; 1981). The equilibrium value for the ${ }^{95} \mathrm{Zr} /{ }^{95} \mathrm{Nb}$ ratio is approximately 0.45 and the highest value of 0.71 observed for the March samples does infer that the ${ }^{95} \mathrm{Zr}$ contained in these samples is of more recent origin relative to other samples which had a ratio of $\sim 0.45$ to 0.55 . Similarly, the ${ }^{137} \mathrm{Cs} /{ }^{134} \mathrm{Cs}$ ratio will increase with time owing to the short half-life of ${ }^{134} \mathrm{Cs}$ relative to that of ${ }^{137} \mathrm{Cs}$; the lowest value of 12.5 observed for the March samples appears to confirm that they contain nuclides of more recent origin relative to samples taken at other times of the year. The ${ }^{137} \mathrm{Cs} /{ }^{134} \mathrm{Cs}$ ratio minimum of 12.5 and the ${ }^{95} \mathrm{Zr} /{ }^{95} \mathrm{Nb}$ ratio maximum of 0.71 , measured at the end of March 1981, both indicate that material of more recent origin was reaching the mussel bed during this period.

\section{Physiological factors influencing radionuclide content}

The nutritional state of the mussel will vary considerably throughout the year depending on a variety of interrelated factors including food availability (Bayne, 1976), temperature (Bayne, 1975), byssus production, gametogenesis and spawning (Pieters et al., 1979, 1980). In addition, any effect of stress due to the translocation of the mussels may affect metabolic activity and hence the depuration rate of radionuclides. The total lipid concentration, water content, average total dry weight per individual and the C. I. were selected 
Table 2. Concentration of various radionuclides in sediment, suspended material, faeces and water taken from the Esk estuary in January 1980 . Errors are for $1 \sigma$ about the mean of triplicate determinations. ND $=$ not determined. ${ }^{\bullet} \mathrm{p} \mathrm{Ci} \mathrm{g}^{-1} \mathrm{dry}$ weight. $\boldsymbol{\bullet}^{\cdot} \mathrm{Bq}$ $\mathrm{g}^{-1}$ dry weight $(1 \mathrm{~Bq}=27 \mathrm{pCi}) . \cdots$ Faeces determined gravimetrically $=15.2 \pm 1.0 \mathrm{mg} \mathrm{g}^{-1}$ dry tissue. (The weight of faeces collected from 50 to 60 Ravenglass mussels over 48-h depuration period was equivalent to $15.2 \pm 1.0 \mathrm{mg}$ of faecal material per $\mathrm{g}$ of dried mussel tissue). $\cdots$ Salinity $=30.34 \% \mathrm{~S}$

\begin{tabular}{|c|c|c|c|c|c|c|c|c|c|}
\hline \multirow[b]{2}{*}{ Isotope } & \multirow[b]{2}{*}{$\begin{array}{l}\text { Waber- } \\
\text { thwaite } \\
\text { sediment }\end{array}$} & \multirow[b]{2}{*}{$\begin{array}{l}\text { Viaduct } \\
\text { sediment }\end{array}$} & \multirow[b]{2}{*}{$\begin{array}{l}\text { Mussel-bed } \\
\text { sediment }\end{array}$} & \multirow{2}{*}{$\begin{array}{c}4 \\
\text { Suspended } \\
\text { material }\end{array}$} & \multicolumn{2}{|c|}{$\begin{array}{c}5 \\
\text { Faeces } \cdots\end{array}$} & \multirow{2}{*}{$\begin{array}{c}5 \\
\text { Water } \cdots . . \\
\text { Sampled at } \\
\text { high-tide } \\
\text { p Ci l } l^{-1} \\
\left(\mathrm{~Bq} \mathrm{l}^{-1}\right)\end{array}$} & \multicolumn{2}{|c|}{$\begin{array}{c}6 \\
\text { Ravenglass mussels }\end{array}$} \\
\hline & & & & & $\begin{array}{c}\text { from } \\
\text { low-water } \\
\text { mussels }\end{array}$ & $\begin{array}{c}\text { from } \\
\text { high-water } \\
\text { mussels }\end{array}$ & & $\begin{array}{c}\text { Not } \\
\text { depurated }\end{array}$ & $\begin{array}{c}\text { 48-h } \\
\text { depuration }\end{array}$ \\
\hline${ }^{95} \mathrm{Zr}$ & $\begin{array}{c}83.9 \pm 7.6^{\circ} \\
(3.11)^{\circ}\end{array}$ & $\begin{array}{c}20.4 \pm 1.9 \\
(0.76)\end{array}$ & $\begin{array}{c}28.1 \pm 2.3 \\
(1.04)\end{array}$ & $\begin{array}{c}47.2 \pm 4.0 \\
\quad(1.75)\end{array}$ & $\begin{array}{c}93.9 \pm 8.1 \\
(3.48)\end{array}$ & $\begin{array}{c}129.7 \pm 9.8 \\
(4.80)\end{array}$ & ND & ND & ND \\
\hline${ }^{134} \mathrm{Cs}$ & $\begin{array}{c}7.7 \pm 2.1 \\
(0.29)\end{array}$ & $\begin{array}{c}11.6 \pm 3.2 \\
(0.44)\end{array}$ & $\begin{array}{c}4.2 \pm 1.0 \\
(0.16)\end{array}$ & $\begin{array}{c}8.1 \\
(0.3)\end{array}$ & $\begin{array}{c}2.9 \pm 0.9 \\
(0.15)\end{array}$ & $\begin{array}{c}3.5 \pm 1.2 \\
(0.13)\end{array}$ & ND & $\begin{array}{c}2.0 \pm 0.9 \\
(0.07)\end{array}$ & $\begin{array}{c}1.65 \pm 0.8 \\
(0.06)\end{array}$ \\
\hline${ }^{137} \mathrm{Cs}$ & $\begin{array}{c}127.2 \pm 14.1 \\
(4.71)\end{array}$ & $\begin{array}{c}137.8 \pm 16.3 \\
(5.10)\end{array}$ & $\begin{array}{c}95.9 \pm 8.1 \\
(3.55)\end{array}$ & $\begin{array}{c}209.3 \pm 20.1 \\
\quad(7.75)\end{array}$ & $\begin{array}{c}124.7 \pm 15.2 \\
(4.62)\end{array}$ & $\begin{array}{c}174.0 \pm 21.4 \\
(6.44)\end{array}$ & $\begin{array}{c}20.8 \pm 21.2 \\
(7.70)\end{array}$ & $\begin{array}{c}31.9 \pm 2.1 \\
(1.18)\end{array}$ & $\begin{array}{c}26.9 \pm 2.0 \\
(1.00)\end{array}$ \\
\hline${ }^{239} \mathrm{Pu}$ & $\begin{array}{c}95.2 \pm 5.0 \\
\quad(3.53)\end{array}$ & $\begin{array}{c}200.5 \pm 10.4 \\
(7.43)\end{array}$ & $\begin{array}{c}45.2 \pm 2.4 \\
(1.67)\end{array}$ & $\begin{array}{c}87.4 \pm 5.2 \\
(3.24)\end{array}$ & $\begin{array}{c}85.4 \pm 5.0 \\
\quad(3.16)\end{array}$ & $\begin{array}{c}136.6 \pm 6.2 \\
(5.06)\end{array}$ & $\begin{array}{c}0.40 \pm 0.08 \\
(0.015)\end{array}$ & $\begin{array}{c}3.80 \pm 0.31 \\
(0.14)\end{array}$ & $\begin{array}{c}2.50 \pm 0.27 \\
(0.09)\end{array}$ \\
\hline $\begin{array}{l}239+240 \\
\mathrm{Pu} /{ }^{238} \mathrm{Pu}\end{array}$ & $3.7 \pm 0.3$ & $4.2 \pm 0.4$ & $3.3 \pm 0.3$ & $3.1 \pm 0.4$ & $3.8 \pm 0.4$ & $3.5 \pm 0.4$ & $1.9 \pm 0.4$ & $\begin{array}{c}3.19 \pm 0.37 \\
(0.12)\end{array}$ & $2.50 \pm 0.35$ \\
\hline${ }^{211} \mathrm{Am}$ & $\begin{array}{c}62.9 \pm 8.3 \\
(2.33)\end{array}$ & $\begin{array}{c}176.1 \pm 11.1 \\
\quad(6.52)\end{array}$ & $\begin{array}{c}36.3 \pm 4.0 \\
\quad(1.34)\end{array}$ & $\begin{array}{c}69.1 \pm 8.0 \\
(2.56)\end{array}$ & $\begin{array}{c}58.8 \pm 7.6 \\
(2.18)\end{array}$ & $\begin{array}{c}130.7 \pm 16.2 \\
(4.84)\end{array}$ & ND & $\begin{array}{c}5.6 \pm 0.7 \\
(0.21)\end{array}$ & $\begin{array}{c}3.36 \pm 0.60 \\
(0.12)\end{array}$ \\
\hline
\end{tabular}

Table 3. Mytilus edulis. ${ }^{95} \mathrm{Zr} /{ }^{95} \mathrm{Nb}$ and ${ }^{137} \mathrm{Cs} /{ }^{134} \mathrm{Cs}$ ratios in total soft tissue of Ravenglass mussels sampled October 1980 to September 1981 at approximately $6 \mathrm{wk}$ intervals. Errors calculated from propagated counting errors of individual isotopes at the $1.65 \sigma$ level. $\cdot$ Discharge data taken from BNFL (1981)

\begin{tabular}{|ccc|}
\hline Date & ${ }^{95} \mathrm{Zr} /{ }^{95} \mathrm{Nb}$ & ${ }^{137} \mathrm{Cs} /{ }^{134} \mathrm{Cs}$ \\
\hline 17. 10. 81 & $0.59 \pm 0.06$ & $15.0 \pm 0.1$ \\
12. 1. 81 & $0.51 \pm 0.06$ & $16.2 \pm 0.2$ \\
17. 2. 81 & $0.68 \pm 0.07$ & $15.7 \pm 0.1$ \\
25. 3. 81 & $0.71 \pm 0.07$ & $12.5 \pm 0.1$ \\
5. 5. 81 & $0.43 \pm 0.06$ & $17.1 \pm 0.2$ \\
1. 6. 81 & $0.46 \pm 0.06$ & $16.0 \pm 0.2$ \\
29. 6. 81 & $0.51 \pm 0.06$ & $26.4 \pm 0.2$ \\
25. 8. 81 & $0.52 \pm 0.07$ & $17.8 \pm 0.2$ \\
24. 9. 81 & $0.56 \pm 0.07$ & $22.0 \pm 0.2$ \\
Discharge $1979^{\circ}$ & 0.61 & 10.9 \\
Discharge $1980^{\circ}$ & 0.59 & 12.4 \\
\hline
\end{tabular}

as simple indices for the relative condition of the Esk and Millbay transplant populations (Fig. $4 \mathrm{a}, \mathrm{b}$ ).

The overall variation in lipid concentration, water content and total dry weight per mussel of the transplanted individuals at Millbay is similar to the resident population at Ravenglass. If, as stated by Pieters et al.
(1979), in Mytilus edulis the annual cycle of water content alternates with the glycogen cycle then the curves shown in Fig. 4a are consistent with this observation, namely that protein and glycogen reserves build up in summer, decrease rapidly in late autumn and winter, and attain minima in spring when lipid contents once more rise.

Apart from the early autumn period when food availability is markedly different at the 2 sites, the C. I. profiles for the transplant mussels and the Ravenglass residents are very similar over the period September 1980 to September 1981 (Fig. 4b). In addition, the C. I. profiles for the transplant mussels are also very similar to those determined by Worral and Widdows (1982) for the Lynher mussel population (Fig. 4b) situated some 5 miles further up the Tamar estuary (Fig. 1), over the same time period. These results, together with the very low mortality rate of the transplant population $(<2 \%$ over the year), indicate that any physiological or biochemical changes induced by translocation would have a negligible effect on depuration.

The growth of these mussels (as defined by increase in total soft tissue weight) cannot be described by a continuous increase in weight throughout the year as an individual's soft tissue weight may vary by as much as a factor 2 (up or down) during that period. Therefore 


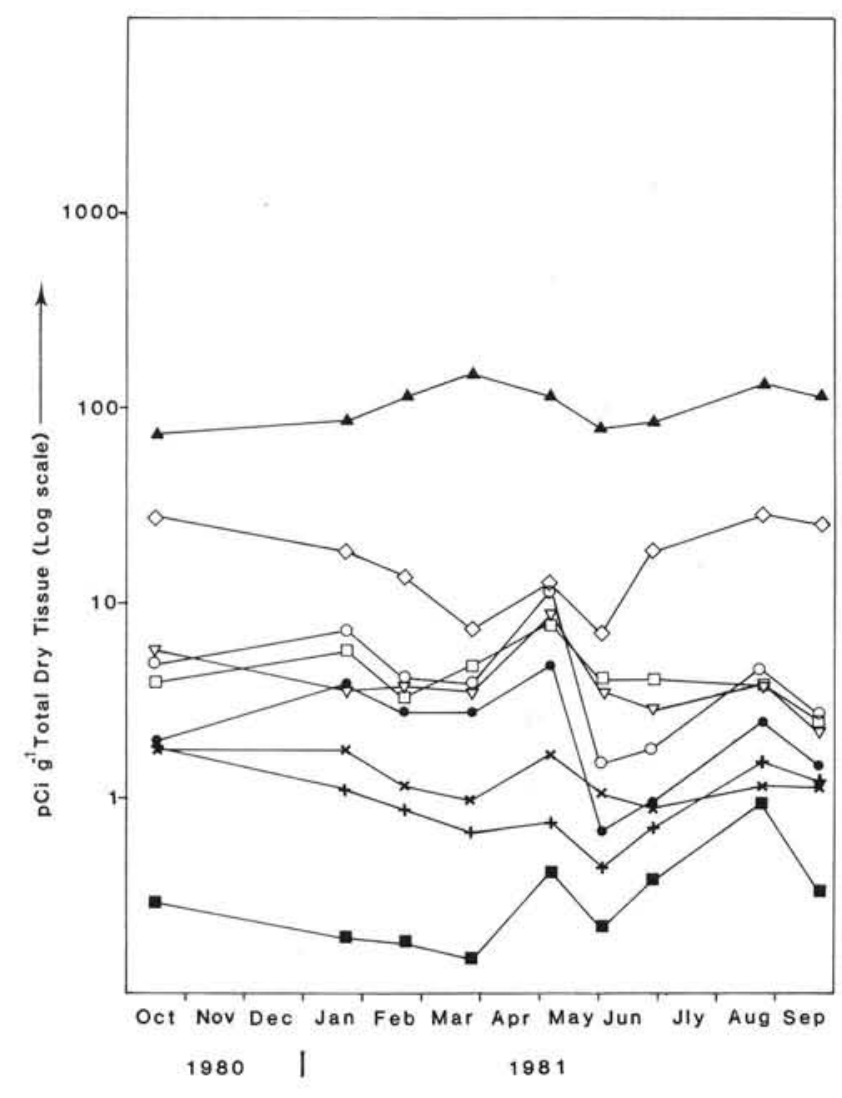

Fig. 3. Mytilus edulis. Weight corrected concentration of ${ }^{106} \mathrm{Ru}$ $(\mathbf{\Delta}),{ }^{137} \mathrm{Cs}(\diamond),{ }^{134} \mathrm{Cs}(+),{ }^{95} \mathrm{Nb}(0),{ }^{241} \mathrm{Am}(\nabla),{ }^{239+240} \mathrm{Pu}(\square),{ }^{95} \mathrm{Zr}$ $(\bullet),{ }^{144} \mathrm{Ce}(\times)$ and ${ }^{60} \mathrm{Co}(\bullet)$ in total soft tissue of Ravenglass mussels, determined throughout October 1980 to September 1981. Propagated counting errors were less than $10 \%$ for ${ }^{60} \mathrm{Co}$, and less than $5 \%$ for all other radionuclides determined

any estimate of weight change, must be made with reference to another parameter which remains essentially constant over the period of interest. Owing to the fact that shell thickness and body volume may vary considerably from individual to individual, the shell cavity volume was considered to be the most reliable index of weight changes.

For the purposes of this work, therefore, the C. I. is the most relevant parameter as it is a useful measure of the physiological condition of the mussel (Goldberg et al., 1978), related to its nutrient state which, in turn, may be used to study the effects of cyclic changes in tissue weight on the concentration of the radionuclides which are retained.

The magnitude of the effect of soft tissue weight variation on the radionuclide concentration will depend upon such factors as uptake and depuration time constants, degree of synchrony between the variation in seasonal growth of the Esk residents and discharge patterns of the radionuclides. For transplant mussels, removed from the source of contamination, we have attempted to resolve these problems by com- paring the depuration rates of the radionuclides calculated from data before and after applying a normalisation procedure based on the average C. I. for each batch of mussels:

$$
\begin{aligned}
& \mathrm{CI}_{\mathrm{o}}=\text { condition index at time }=\mathrm{o} \\
& \mathrm{CI}_{\mathrm{t}}=\text { condition index at time }=\mathrm{t}
\end{aligned}
$$

and $\mathrm{X}_{\mathrm{t}}=$ concentration of radionuclide at time $\mathrm{t}$ then the concentration of the radionuclide $\left(\mathrm{X}_{\mathrm{n}}\right)$ at time $t$, normalised to the C. I. at $t_{\mathrm{o}}$, is given by:

$$
\mathrm{X}_{\mathrm{n}}=\mathrm{X}_{\mathrm{t}} \times \mathrm{CI}_{\mathrm{t}} / \mathrm{CI}_{\mathrm{o}}
$$

Table 4 compares depuration rates before and after C. I. normalisation. From the analyses of variance about the corrected and uncorrected curves this normalisation has resulted in a reduction in the standard deviation of measurements in all cases, thus endorsing the findings of Bayne et al. (1981). For ${ }^{241} \mathrm{Am}$, ${ }^{239}+{ }^{240} \mathrm{Pu},{ }^{238} \mathrm{Pu}$ and ${ }^{144} \mathrm{Ce}$ radioactive decay curves, variability has been reduced by between 35 and $56 \%$. By applying the normalisation factor (Equation 1) it is possible to determine not only depuration rates, but also to differentiate between radionuclide concentration changes induced by a variation of the source term from that caused by soft tissue weight changes.

\section{Depuration}

The depuration curves, corrected for weight changes of the mussel and the physical radioactive decay of the isotope $\left({ }^{241} \mathrm{Am},{ }^{239}+{ }^{240} \mathrm{Pu},{ }^{238} \mathrm{Pu},{ }^{144} \mathrm{Ce},{ }^{137} \mathrm{Cs}\right.$ and $\left.{ }^{106} \mathrm{Ru}\right)$ are shown in Fig. $5 \mathrm{a}, \mathrm{b}$ and c. The data are represented as a percentage of the isotope content of the whole soft tissue at the beginning of the experiment. With the exception of ${ }^{106} \mathrm{Ru}$, which appears to depurate according to a 3-component system, the remainder of the isotopes studied depurate according to a 2-component system with just over $50 \%$ of the activity in the shortterm compartment and just under $50 \%$ in the longterm compartment (Table 4). Guary and Fowler (1981), however, have identified a 3-compartment system for the loss of ${ }^{241} \mathrm{Am}$ and ${ }^{237} \mathrm{Pu}$ from Mytilus galloprovincialis. A variety of factors, apart from the choice of indicator species, may be responsible for the observed differences between both sets of data: Guary and Fowler's data includes radionuclides associated with the shell in the calculation of biological half-lives, and their mussels were exposed to tracers for $28 \mathrm{~d}$ in the laboratory; in our study the mussels have been chronically exposed under environmental conditions for the whole of their life-span of 7-10 yr Hamilton (1980). Van Weers (1973) suggests that the biological half-life of an isotope is a function of its uptake time. It is probable, therefore, that incomplete equilibration of the indicator species with the tracer is the primary 

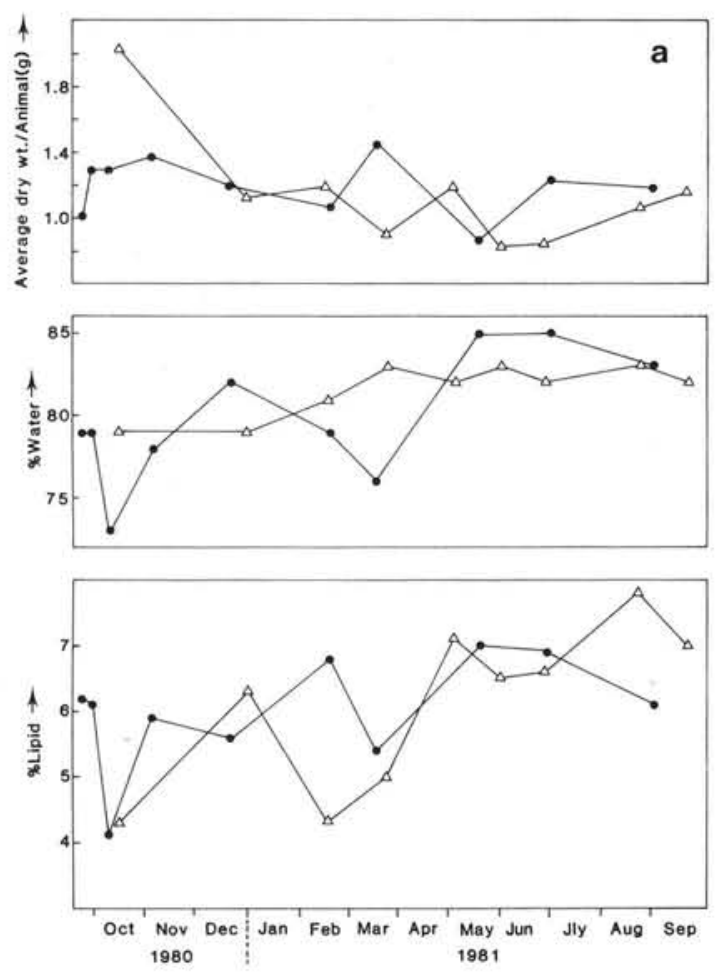

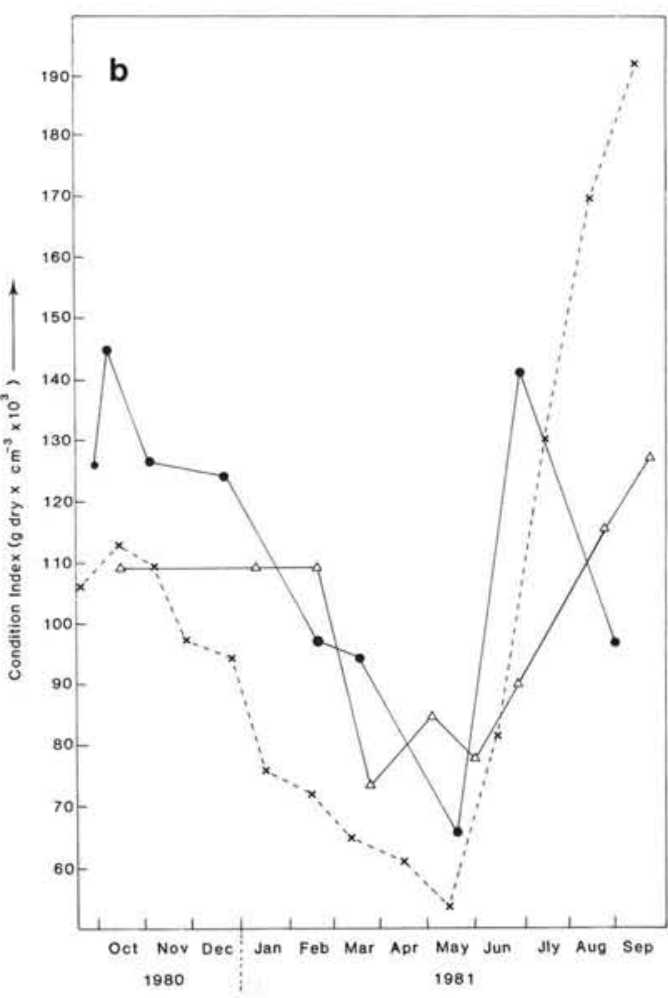

Fig. 4. Mytilus edulis. (a) Comparison of variation in average dry weight per individual, water content and lipid content of resident Ravenglass mussels $(\Delta)$ to that of the Millbay transplant population (•). October 1980 to September 1981. In all cases the precision on triplicate determinations was better than $8 \%(1 \sigma)$. (b) Comparison of variation in CI of Ravenglass residents $(\Delta)$ to that of the Millbay transplant population ( $\bullet$ ). The CI determined by Worrall and Widdows (1981) for Lynher mussels $(\times)$ has also been included. Errors: 20 to $25 \%$ about the mean of 12 to 15 determinations ( 1 \%)
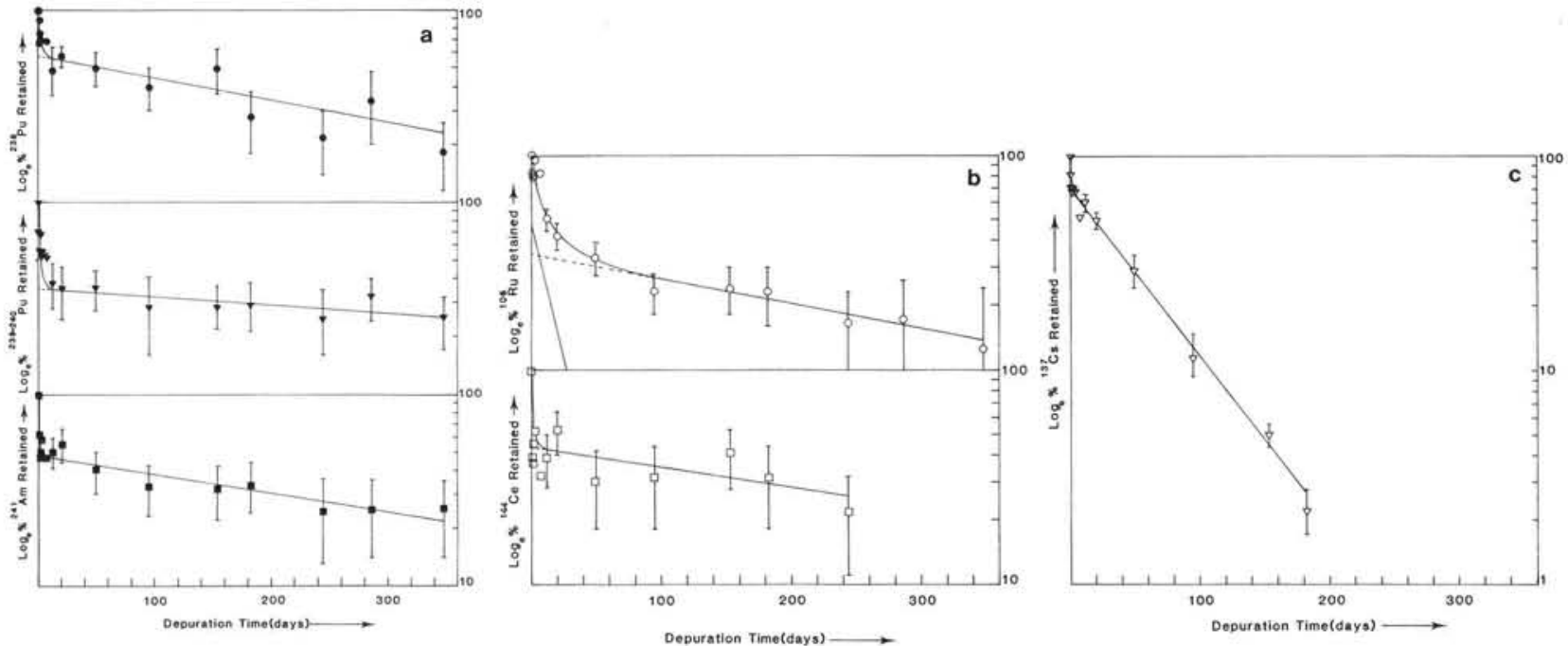

Fig. 5 (a to c). Depuration profiles of ${ }^{238} \mathrm{Pu}(\bullet),{ }^{239+240} \mathrm{Pu}(\boldsymbol{\nabla}),{ }^{241} \mathrm{Am}(\bullet),{ }^{144} \mathrm{Ce}(\square),{ }^{137} \mathrm{Cs}(\nabla)$ and ${ }^{106} \mathrm{Ru}(\mathrm{O})$. Error bars associated with the long component are for $1 \sigma$ (counting error). For clarity, errors not included over early depuration period and short-term depuration component not presented graphically. Intermediate component for ${ }^{106} \mathrm{Ru}$, however (Fig. $5 \mathrm{~b}$ ) included

reason for the somewhat different estimates of biological half-lives quoted in the literature. (Fowler et al., 1975; Guary and Fowler, 1981).

While ${ }^{144} \mathrm{Ce}$ shows similar depuration characteristics to ${ }^{241} \mathrm{Am}$ and the plutonium isotopes, ${ }^{106} \mathrm{Ru}$ and ${ }^{137} \mathrm{Cs}$ are very different; ${ }^{137} \mathrm{Cs}$ has a 2 -component decay, the longer component having a much shorter biological half-life than the actinides, i. e. $39 \mathrm{~d}$-possibly reflecting the greater solubility of this nuclide in sea water. The depuration of ${ }^{106} \mathrm{Ru}$ is best described by a 3- 


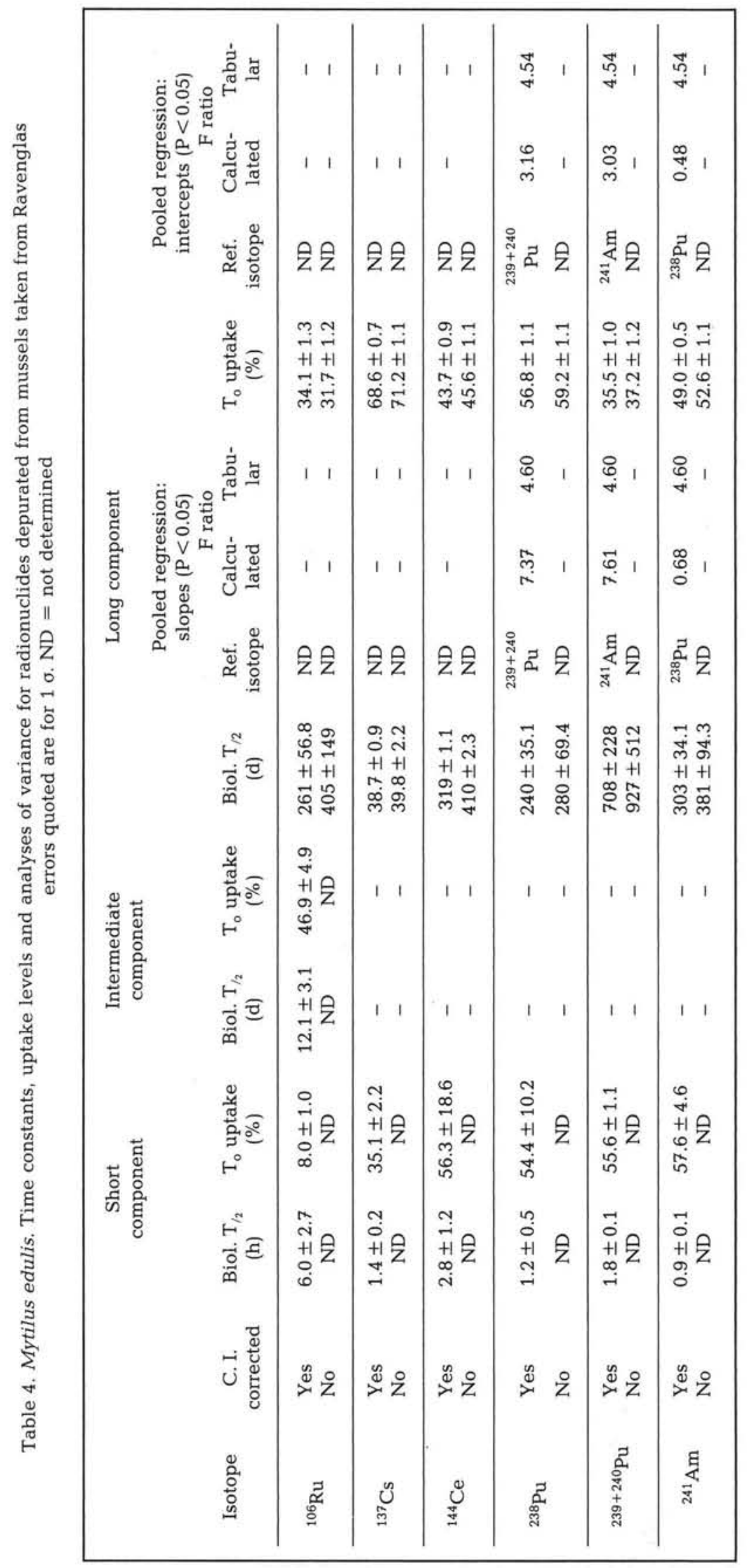


component system: the longest being similar to that of the actinides; the shortest is significantly greater $(6 \mathrm{~h}$ as opposed to 1 to $3 \mathrm{~h}$ for the actinides) and there is an intermediate component having a biological half-life of approximately $12 \mathrm{~d}$. This rather unique behaviour of ${ }^{106} \mathrm{Ru}$, relative to the other isotopes studied, is probably a function of the complexity of its chemical state and its affinity for biological material (Nishiwaki et al., 1975; Keckes et al., 1966, 1967).

With the exception of ${ }^{106} \mathrm{Ru}$ the short component of the other isotopes studied is due essentially to clearance rates from the digestive tract. From the gravimetric determination of faeces it has been calculated that a sediment content of $15 \mathrm{mg} \mathrm{g}^{-1}$ dry tissue is equivalent to more than $90 \%$ of the activity lost during the first 24 h. With the exception of ${ }^{106} \mathrm{Ru}$, the longer component of all the isotopes studied accounts for nearly all of the isotope incorporated into the soft tissue.

The biological half-lives, and the percentage uptake values calculated for ${ }^{238} \mathrm{Pu},{ }^{239}+240 \mathrm{Pu}$ and ${ }^{241} \mathrm{Am}$ (Table 4), indicate that there are differences between these isotopes with respect to the long depuration component. An analysis of variance on a pooled regression of individual pairs shows that there is a significant difference between the biological half-life of ${ }^{239+240} \mathrm{Pu}$ to that of both ${ }^{238} \mathrm{Pu}$ and ${ }^{241} \mathrm{Am}$.

Differences between the biological affinities of ${ }^{241} \mathrm{Am}$ relative to plutonium isotopes have been reported (Pentreath, 1981), and several authors (Hakanson, 1973; Emery, 1974a and 1974b; Volchock, 1975) have reported a difference in the biological affinities of individual plutonium isotopes in the terrestrial and aquatic environment as well as in the laboratory (Thompson, 1967; Mahlum, 1969, and Bair, 1974). Beasley and Fowler (1976) could not detect any preferential accumulation of ${ }^{238} \mathrm{Pu}$ over ${ }^{239+}{ }^{240} \mathrm{Pu}$ in polychaete worms kept in sediments contaminated with these isotopes in a variety of ways. They suggest that any differences found in the biological affinities of these 2 isotopes can be a reflection of errors caused by inadequate analytical techniques. While accepting Beasley and Fowler's argument that scrupulous attention should be paid to radiochemical purity, it is not possible to ascribe the differences between ${ }^{239}+{ }^{240} \mathrm{Pu}$ and ${ }^{238} \mathrm{Pu}$, observed in this work, within the limits of their arguments as:

(a) The radiochemical separation of the plutonium isotopes was specifically designed to separate them from both the naturally occurring $\alpha$-emitting radionuclides as well as the man-made nuclides, such as ${ }^{241} \mathrm{Am}$ (Livingstone, 1975); our preliminary experiments indicated that $<1 \%$ of both ${ }^{241} \mathrm{Am}$ and ${ }^{228} \mathrm{Th}$ are carried through the method and would not interfere with the ${ }^{238} \mathrm{Pu}$ determination.

(b) There are no naturally occurring isotopes with significant $\alpha$-emissions in the same energy region as ${ }^{239}+{ }^{240} \mathrm{Pu}$ (i. e. 5.1 to $5.2 \mathrm{MeV}$ ). $\alpha$-emitting contaminants falling in the same energy region as the ${ }^{236} \mathrm{Pu}$ tracer would result in an erroneous estimate of concentration, but could not cause the observed differences between the depuration profiles of ${ }^{239+240} \mathrm{Pu}$ and ${ }^{238} \mathrm{Pu}$.

It should be emphasized, however, that the apparent differences between the ${ }^{239} \mathrm{Pu}$ and ${ }^{238} \mathrm{Pu}$, and possibly ${ }^{241} \mathrm{Am}$, are based on normalised data points, often with fairly high variability and must be interpreted accordingly. In addition, the long depuration component for the actinides is necessarily calculated from a very shallow slope which is extremely sensitive to small variations in isotope concentration; and although the biological half-life for ${ }^{239}+{ }^{240} \mathrm{Pu}$ is significantly different from both ${ }^{238} \mathrm{Pu}$ and ${ }^{241} \mathrm{Am}$ this difference is probably not as great as that indicated by the 708,267 and $304 \mathrm{~d}$ half-lives quoted in Table 4. It is extremely unlikely that these differences are caused by the mussel differentiating between ${ }^{238} \mathrm{Pu}$ and ${ }^{239}+{ }^{240} \mathrm{Pu}$ per se and one possible explanation must be that these isotopes are in different physico-chemical forms, either as a result of processing and storage prior to discharge from BNFL or sediment-water interactions after discharge (Murray and Murray, 1973; Murray and Fukai, 1975; Edgington, 1981). Apart from Koide et al. (1981), the primary route of entry of $\mathrm{Pu}$ and many other radioisotopes present in the soft tissues of the mussel is by intake, via the gills, of dissolved species from the water (Noshkin et al., 1971; Fowler et al., 1975; Bryan, 1976; Coombs, 1977). From Table 2 it can be seen that

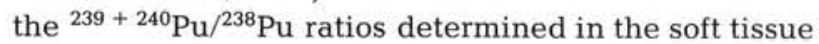
of the mussel are much closer to those found in sea water than those found in either sediment or faeces, a fact which may be explained by a difference in redox potential (Nelson and Lovett, 1978, 1981) of the dissolved $\mathrm{Pu}$ isotope relative to those associated with the sediment and one which may influence the uptake and depuration rates of these isotopes (Fowler et al., 1975).

\section{CONCLUSIONS}

The contents of the mussel's digestive tract reflect the presence of sediment with higher radioactivities towards the high tidal levels. The influence of tidal position and mussel size (shell length) on the concentration of ${ }^{241} \mathrm{Am},{ }^{137} \mathrm{Cs}$ and ${ }^{106} \mathrm{Ru}$, associated with the total soft tissue, is negligible.

Variation in total soft tissue weight, as indicated by the C. I. of the mussel, will have a profound influence on the concentration of the radionuclides retained. This may result in an apparent difference, of more than a factor of 2 , between the concentration of radionuc- 
lides observed in late summer to that in winter, independent of the source function.

Apart from clearance from the digestive tract the depuration of all the isotopes studied, with the exception of ${ }^{106} \mathrm{Ru}$, from the total soft tissue of the mussel follow a single-component system, with the more insoluble species - such as ${ }^{241} \mathrm{Am},{ }^{239+}{ }^{240} \mathrm{Pu},{ }^{238} \mathrm{Pu}$ and ${ }^{144} \mathrm{Ce}$ - having a biological half-life in excess of $200 \mathrm{~d}$; the presumed soluble nuclides, such as ${ }^{137} \mathrm{Cs}$, have a much shorter biological half-life of approximately $40 \mathrm{~d}$. The depuration of ${ }^{106} \mathrm{Ru}$ is more complex, however, as a result of its affinity for organic material associated with the complexity of its chemical forms (Nishiwaki et al., 1975). These factors may also be responsible for the rather unique manner in which the concentration of this isotope varies, relative to the other isotopes studied in the Ravenglass population throughout the year.

Although sediment/water interactions may influence both the chemical form and concentration of nuclides in solution, the primary route of entry of these radioisotopes, into the mussel, is likely to be by direct uptake of soluble species, and not by leaching processes associated with the digestive tract.

Differences in uptake levels and biological half-lives of ${ }^{239+}{ }^{240} \mathrm{Pu}$ relative to those of ${ }^{238} \mathrm{Pu}$ and ${ }^{241} \mathrm{Am}$ are difficult to explain satisfactorily. However, this feature has been observed elsewhere on numerous occasions and cannot always be associated with inadequate analytical techniques.

These differences may reflect the fact that the mussels are being exposed to these isotopes in different physico-chemical forms resulting from treatment prior to discharge (a source term for which there is little or no data) or sediment/water interactions after discharge. Any explanation for these phenomena, involving differences in specific activities (Herring and Perkowski, 1975) and $\alpha$-recoil (Fleischer and Raabe, 1978; Fleischer, 1980), must be considered speculative at this stage.

In this study we have only looked at the concentration and loss of radionuclides from the total soft tissue of the mussel. Many radioisotopes are also strongly associated with the shell (Gaury and Fowler, 1981) particularly the periostracum (Hamilton and Clifton, 1980 ), and this is the subject of further study.

Acknowledgements. The authors wish to thank: Dr. K. R. Clarke and Mr. P. J. Radford for advice on statistical analyses; Dr. B. L. Bayne, Dr. J. Widdows and Mr. C. M. Worrall and members of the IMER Experimental Ecology Group and Dr. S. W. Fowler (IAEA, Monaco) for advice and helpful discussions; Dr. D. Horril, NERC Institute of Terrestrial Ecology, for assistance in collecting samples and further discussions.

This work forms part of the Environmental Radioactivity Programme of the Institute for Marine Environmental
Research, a component of the Natural Environment Research Council, and was supported in part by funds provided by the European Economic Community, contract B10-B-438-81-UK.

\section{LITERATURE CITED}

Aston, S. R., Stanners, D. A. (1982). Gamma emitting fission products in surface sediments of the Ravenglass estuary. Mar. Pollut. Bull. 13: 135-138

Bair, W. J., Willard, D. H., Nelson, I. C., Case, A. C. (1974). Comparative distribution and excretion of ${ }^{237} \mathrm{Pu}$ and ${ }^{239} \mathrm{Pu}$ nitrates in beagle dogs. Hlth Phys. 27: 392-396

Bayne, B. L. (1975). Reproduction in bivalve molluscs under environmental stress. In: Vernberg, F. J. (ed.) Physiological ecology of estuarine organisms. University of South Carolina Press, Columbia, p. 259-277

Bayne, B. L. (1976). Marine mussels, their ecology and physiology. IBP No. 10, Cambridge University Press, London

Bayne, B. L., Widdows, J. (1978). The physiological ecology of two populations of Mytilus edulis L. Oecologia 37: 137-162

Bayne, B. L., Clarke, K. R., Moore, M. N. (1981). Some practical consideration in the measurement of pollution effects in bivalve molluscs and some possible ecological consequences. Aquatic toxicology 1981: 159-174

Beasley, T. M., Fowler, S. W. (1976). Plutonium isotope ratios in polychaete worms. Nature, Lond. 262: 813-814

BNFL (1981). Annual report on radioactive discharges and monitoring of the environment 1980. (Issued by Director of Health and Safety UK). Risley, Warrington, Cheshire, U. K.

Bligh, E. G., Dyer, W. J. (1959): A rapid method of total lipid extraction and purification. Can. J. Biochem. Physiol. 37. 911-917

Bowen, V. T., Livingstone, H. D., Burke, J. C. (1976). Distributions of transuranium nuclides in sediment and biota of the North Atlantic Ocean. In: International symposium on transuranium nuclides in the environment, IAEA, Vienna, p. $107-120$

Bryan, G. W. (1976). Heavy metal contamination of the sea. In: Johnston, R. (ed.) Marine pollution. Academic Press, London, p. 185-302

Clifton, R. J., Hamilton, E. I. (1982). The application of radioisotopes in the study of estuarine sedimentary processes. Estuar. coast. mar. Sci. 14: 438-446

Coombs, T. L. (1977). Uptake and storage mechanism of heavy metals in marine organisms. Proc. Anàlyt. Div. Chem. Soc. 14: 212-222

Dahlgaard, H. (1981). Loss of ${ }^{51} \mathrm{Cr},{ }^{54} \mathrm{Mn},{ }^{57} \mathrm{Co},{ }^{59} \mathrm{Fe},{ }^{65} \mathrm{Zn}$ and ${ }^{134} \mathrm{Cs}$ by the mussel Mytilus edulis. In: International symposium on the impacts of radionuclide releases into the marine environment, IAEA, Vienna, p. 361-370

Edgington, D. N. (1981). A review of the persistence of longlived radionuclides in the marine environment - sediment/water interactions. In: International symposium on impacts of radionuclide release into the marine environment, IAEA, Vienna, p. 67-92

Emery, R. M., Klopher, D. C., Weimer, W. C. (1974a). Ecological behaviour of plutonium and americium in a freshwater ecosystem. Phase I. Limnological characterization and isotopic distribution. BNWL-1867, UC-48, 1-76, Battelle Pacific North-West Laboratory, Sequim, Wash.

Emery, R. M., Garland, T. R. (1974b). Ecological behaviour of plutonium and americium in a freshwater ecosystem. Phase II. Implications of differences in transuranic isotopic 
ratios. BNWL-1879, UC-48, 1-26, Battelle Pacific NorthWest Laboratory

Fleischer, R. L., Raabe, O. G. (1978). Recoiling alpha-emitting nuclei: mechanisms for uranium - series disequilibrium. Geochem. Cosmochim. Acta 42: 973-978

Fleischer, R. L. (1980). Isotopic disequilibrium of uranium: alpha recoil damage and preferential solution effects. Science, N. Y. 207: 979-981

Fowler, S. W., Heyraud, M., Beasley, T. M. (1975a). Experimental studies on plutonium kinetics in marine biota. In: International symposium on impacts of nuclear releases into the aquatic environment, IAEA, Vienna, p. 157-177

Fowler, S. W., La Rosa, J., Heyraud, M., Renfro, W. C. (1975b). Effect of different radiotracer labelling techniques on radionuclide excretion from marine organisms. Mar. Biol. 30: $297-304$

Fowler, S. W., Benayoun, G., Parsi, P., Essa, M. W. A., Schulte, E. H. (1981). Experimental studies on the bioavailability of technetium in selected marine organisms. In: International symposium on impacts of radionuclide releases into the marine environment, IAEA, Vienna, p. 319-340

Goldberg, E. D., Bowen, V. T., Farrington, J. W., Harvey, G., Martin, J. H., Parker, P. L., Risebrough, R. W., Robertson, W., Schneider, E., Gamble, E. (1978). The mussel watch. Environ. Conserv. 5: 118-123

Guary, J. C., Fowler, S. W. (1977). Biokinetics of neptunium237 in mussels and shrimp. Mar. Sci. Communs 3: 211-229

Guary, J. C., Fowler, S. W. (1978). Uptake from water and tissue distribution of neptunium-237 in crabs, shrimp and mussels. Mar. Pollut. Bull. 9: 331-334

Guary, J. C., Fowler, S. W. (1981). Americium-241 and plutonium-237 turnover in mussels (Mytilus galloprovincialis) living in field enclosures. Estuar. coast. Shelf Sci. 12: $193-203$

Hakaonson, T. E., Johnson, L. J. (1973). Distribution of environmental plutonium in the Trinity site ecosystem after 27 years. LA-UR-73-1291, 1-6 Los Alamos Scientific Laboratory

Hamilton, E. I. (1980). Concentration and distribution of uranium in Mytilus edulis and associated materials. Mar. Ecol. Prog. Ser. 2: 61-73

Hamilton, E. I., Clifton, R. J. Concentration and distribution of the transuranium radionuclides ${ }^{239}+{ }^{240} \mathrm{Pu},{ }^{238} \mathrm{Pu}$ and ${ }^{241} \mathrm{Am}$ in Mytilus edulis, Fucus vesiculosus and surface sediment of Esk estuary (1980). Mar. Ecol. Prog. Ser. 3: 267-277

Herring, J., Perkowski, J. (1975). Transuranium elements, Ch. 3. In: Assessing potential ocean pollutants, Nat. Academy of Sci., Wash. D. C.

Hetherington, J. A., Jefferies, D. F, Mitchell, N. T., Pentreath, R. J., Woodhead, D. S. (1976). Environmental consequences of the controlled disposal of transuranic elements to the marine environment. In: International symposium on transuranium nuclides in the environment, IAEA, Vienna, p. 139-154

Kěckes, S., Pucar, Z., Marazovic, Lj. (1966). The influence of the physicochemical form of ${ }^{106} \mathrm{Ru}$ on its uptake by mussels from sea water. In: International symposium on radioecology concentration processes, Stockholm. Pergamon, New York, p. 993-999

Keckes, S., Pucar, Z., Marazovic, Lj. (1967). Accumulation of electrodialytically separated physico-chemical forms of ${ }^{106} \mathrm{Ru}$ by mussels. Int. J. Oceanol. Limnol. 246-250

Koide, M., Williams, P. W., Goldberg, E. D. (1981). Am-241/ $\mathrm{Pu}-239+240$ ratios in the marine environment. Mar. environ. Res. 5: 241-246

Livingstone, D. D., Mann, D. R., Bowen, V. T. (1975). Analytical procedures for transuranic elements in sea water and marine sediments. Analytical methods in oceanography. Am. Chem. Soc. Adv. Chem. 1975: 125-138

Mahlum, D. D., Sikov, M. R. (1969). Physicochemical state as a determinant of Plutonium-238 toxicity in the rat. Hlth Phys. 17: 346-347

Murray, C. N., Murray, L. (1973). Adsorption-desorption equilibria of some radionuclides in sediment - fresh water and sediment - sea water systems. In: Symposium on radioactive contamination of the marine environment, IAEA, Vienna, p. 105-124

Murray, C. N., Fukai, R. (1975). Adsorption-desorption characteristics of plutonium and americium with sediment particles in the estuarine environment. In: International symposium on the impacts of nuclear releases into the aquatic environment, IAEA, Vienna, p. 107-120

Murray, C. N., Fukai, R. (1978). Measurement of ${ }^{239+}{ }^{240} \mathrm{Pu}$ in the North western Mediterranean. Estuar. coast. mar. Sci. 6: $145-151$

Nelson, D. M., Lovett, M. B. (1978). Oxidation state of plutonium in the Irish Sea. Nature, Lond. 276: 599-601

Nelson, D. M., Lovett, M. B. (1981). Measurements of the oxidation state and concentration of plutonium in interstitial waters of the Irish Sea. In: Impacts of radionuclide releases into the marine environment, IAEA, Vienna, p. 105-118

Nishiwaki, Y., Honda, Y., Ishiyama, T., Matsumura, T., Mamuro, T. (1975). Environmental behaviour of the binuclear-bridged nitrato-nitrososylruthenium complex. In: International symposium on impacts of nuclear releases into the aquatic environment, IAEA, Vienna, p. 107-120

Noshkin, V. E., Bowen, V. T., Wong, K. M., Burke, C. (1971). Radionuclides in ecosystems. In: Proceedings of the 3rd national symposium on radioecology, Oak Ridge. USAEC Conf-710501, p. 681-686

Noshkin, V. E. (1972). Ecological aspects of plutonium dissemination in aquatic environments. Hlth Phys. 22: 537-549

Pentreath, R. J. (1981). The biological availability to marine organisms of transuranium and other long-lived nuclides. In: International symposium on the impacts of radionuclide releases into the marine environment, IAEA, Vienna, p. 241-272

Pieters, H., Kluytmans, J. H., Zurburg, W., Zandee, D. I. (1979). The influence of seasonal changes on energy metabolism in Mytilus edulis (L.). I. Growth rate and biochemical composition in relation to environmental parameters and spawning. In: Naylor, E., Hartnoll, R. G. (eds.) Cyclic phenomena in marine plants and animals. Pergamon Press, New York, p. 285-293

Pieters, H., Kluytmans, J. H., Zandee, D. I. (1980). Tissue composition and reproduction of Mytilus edulis in relation to food availability. Neth. J. Sea Res. 14: 349-361

Pillai, K. C., Smith, R. C., Folsom, T. R. (1964). Plutonium in the marine environment. Nature, Lond. 203: 568-571

Pillai, K. C., Mathews, E. (1976). Plutonium in the aquatic environment: its behaviour, distribution and significance. In: International symposium on transuranium nuclides in the environment, IAEA, Vienna, p. 25-45

Seymour, A. H., Nelson, V. A. (1973). Decline of ${ }^{65} \mathrm{Zn}$ in marine mussels following the shutdown of Hanford reactors. In: Radioactive contamination of the marine environment, IAEA, Vienna, p. 277-286

The International Mussel Watch (1980). National Academy of Sciences, Washington, D. C.

Thompson, R. C. (1967). A guide to the technology. In: Wick, O. J. (ed.) Plutonium handbook. Gordon \& Breach, New York, p. 785-829 
Thompson, R. J. (1972). Feeding and metabolism in the mussel Mytilus edulis L. Ph. D. thesis, Leicester University

Van Weers, A. W. (1973). Uptake and loss of ${ }^{65} \mathrm{Zn}$ and ${ }^{60} \mathrm{Co}$ by the mussel Mytilus edulis L. In: International symposium on radioactive contamination of the marine environment, IAEA, Vienna, p. 385-401
Volchok, H. L. (1975). Assessing potential ocean pollutants. National Academy of Sciences, Washington, D. C. p. $27-63$

Worrall, C. M., Widdows, J. (Pers. comm.). An investigation into factors influencing mortality in Mytilus edulis.

This paper was submitted to the editor; it was accepted for printing on December 20, 1982 